\title{
中性子源特性試験装置（BL10）
}

及川 健一, 原田 正英

(日本原子力研究開発機構 J-PARC センター)

\section{NeutrOn Beam Line for Observation and Research Use (BL10)}

Kenichi Oikawa and Masahide Harada

J-PARC Center, JAEA

\section{0}

\begin{abstract}
NOBORU was constructed at beam-line no. 10 (BL10) of the Materials and Life Science Experimental Facility (MLF) at J-PARC in 2007. The primary mission of NOBORU is facility diagnostics to study neutronic performance of Japan Spallation Neutron Source (JSNS). Validation methods of unique neutronics design features of JSNS are briefly reviewed.

Keywords: Facility Diagnostics, Design Validation, Neutronic Performance
\end{abstract}

1.はじめに

物質・生命科学実験施設（以下，MLF）の入口 ロビーに, 施設紹介のパンフレットが数種類置か れている．実はそれらのパンフレットは，毎年の ように更新されている。その理由のひとつは， MLF において中性子及びミュオンの実験装置が 毎年のように増えていっているからである.

中性子源特性試験装置（以下，NOBORU）は， それら実験装置群の中で最初に建設された装置で ある. 2008 年 5 月 30 日には, MLF の核破砕中性 子源（以下，JSNS）が発した最初のパルス中性子 を実測した[1]. 本装置建設の背景及び目的の詳細 については以前に本誌で紹介し[2], また初期の装 置利用の様子については, 本誌 2010 年の特集号で 詳述した[3].

その後, 2011 年 3 月の東日本大震災や 2013 年 5 月の J-PARC ハドロン実験施設における放射性物 質漏洩事故といった試練を乗り越え, 加速器出力 の $1 \mathrm{MW}$ 到達ならびにその中性子特性試験が，い よいよ NOBORU の現実の目標に入ってきた.『中 性子源施設として自ら責任を持って中性子ビーム 性能を把握し, JSNS という複雑で巨大なシステム を安定かつ安全に運転し, ユーザーに常時高品質 かつ大強度の中性子を提供する』ことに資する， という NOBORU の存在意義を達成寸るために, 我々が行ってきた事を以下に書きとどめる事とす る. なお本装置は, いわゆるテストポートとして 様々な中性子散乱以外の利用研究が数多く実施さ れているが，それらは紙面の都合で割愛する.
2. 装置の特徵と測定・解析例

2.1 ビームラインの特徴

再び施設紹介のパンフレットを見てみよう。最 後の見開きページに, MLF の三次元イラストが描 かれている.『10』と記されている所には，何やら テーブルらしきものだけがポツンと描かれている. 大きな真空チャンバーも無ければ，検出器も備え られていない。これは本装置の特徵と言っていい だろう. NOBORU の最大の武器は, 強固な遮蔽体 に囲まれた実験室空間そのものである(Fig. 1).

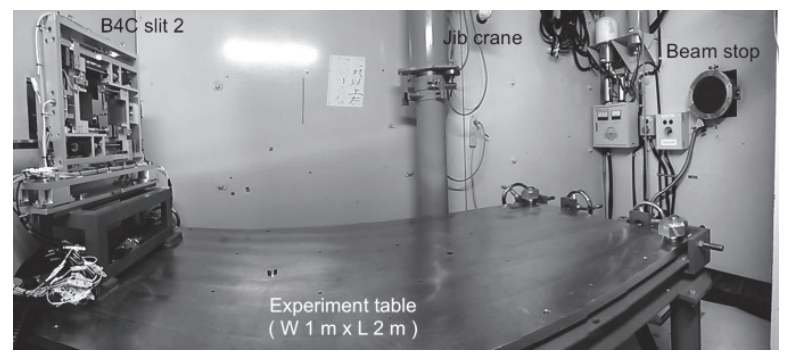

Fig.1 The experimental room of NOBORU; $2.5 \mathrm{~m}$ in width, $3.0 \mathrm{~m}$ in length, and $3.0 \mathrm{~m}$ in height.

Table 1 Specifications of NOBORU.

\begin{tabular}{|c|c|}
\hline Wavelength & $\lambda<10.5 \AA$ (1st frame) \\
\hline Energy & $\mathrm{MeV} \sim \mathrm{meV}(1 \mathrm{st}$ frame $)$ \\
\hline Resolution $(\Delta d / d)$ & $0.33 \% @ 2 \theta=170^{\circ}$ \\
\hline Neutron intensity & $4.8 \times 10^{7} \mathrm{n} / \mathrm{s} / \mathrm{cm}^{2}(<0.4 \mathrm{eV})$ \\
$(@ 14 \mathrm{~m} @ 1 \mathrm{MW})$ & $1.2 \times 10^{7} \mathrm{n} / \mathrm{s} / \mathrm{cm}^{2}(>1 \mathrm{MeV})$ \\
& $1.2 \times 10^{6} \mathrm{n} / \mathrm{s} / \mathrm{cm}^{2}(>10 \mathrm{MeV})$ \\
\hline Beam size & Maximum $10 \times 10 \mathrm{~cm}^{2}$ \\
\hline
\end{tabular}


装置の仕様を Table 1 に示寸. これらの数值は, 主としてニュートロニクス計算がその根拠である が，次節よりその「中性子特性」をいかにして検 証していったかを測定方法ならびに解析プロセス として記す。

\section{2 熱・冷中性子パルス特性}

JSNS 全ビームラインの中性子特性等の数值デ ータファイルは, J-PARC の web 上に公開されて おり, ぞこからでも誰でもダウンロード出来る[4] フォーマットを極僅か修正すれば，そのまま McStas[5]の SNS_source.comp に読み込ませること も出来る.ただし, 本データのパルス形状は, J-PARC 加速器の陽子ビームダブルバンチ構造を 考慮していないため, 数 $\mathrm{eV}$ 以上の共鳴領域では, 実際のパルス形状を再現しない（つまり，シング ルバンチの $1 \mathrm{MW}$ 相当で計算されている).

パルス形状測定法については当初, 池田らによ るタイムフォーカシングを用いた測定方法[6]も 検討したが，実験の第 1 の目的が『寸でにある』 計算值との比較である事, 及びビーム強度も十分 ある事から，通常の $2 d \sin \theta=\lambda の$ 条件の回折実験 とした。また，ビーム強度上昇とともに確認試験 を行う事を重視したため, あえて high-q 領域の回 折強度が取れる低温測定とはせず，実験条件再現 が簡便な室温測定とした。 回折用検出器は現状で 最も信頼がおけ, また検出器遮蔽もしやすい $\phi 1 / 2^{\prime \prime} \times 10 \mathrm{~cm} の{ }^{3} \mathrm{He} の 0$ 次元検出器一本とした. ただし，結晶のアライメントについては 5 軸ゴニ オメータを用い, $2 \theta=170^{\circ}$ に置いた検出器でロッキ ングカーブを測定することで試料の軸立てを行っ た.

冷中性子領域のパルス特性測定には，北大より 提供して頂いた天然マイカを用いた。およそ 20 $\mathrm{meV}(2 \AA)$ から $0.2 \mathrm{meV}(20 \AA)$ の領域でパルス データが測定出来ている (Fig. 2). $20 \mathrm{meV}$ より上 の熱中性子領域では, マイカの結晶性（モザイシ ティと思われる）悪化から，急激な強度低下並び に計算值とのずれが顕著になるため, これより上 のエネルギー領域のパルス特性評価には, BL18

（SENJU）グループからダイヤモンドの単結晶を 借用した（Fig. 3).

Fig. 4 には半值幅と $1 / 100$ 幅の計算値と実測値の 比較データをまとめた。実測したパルス形状が計 算値と非常に良い一致を示している様子は，原著 論文[7]を参照されたい。

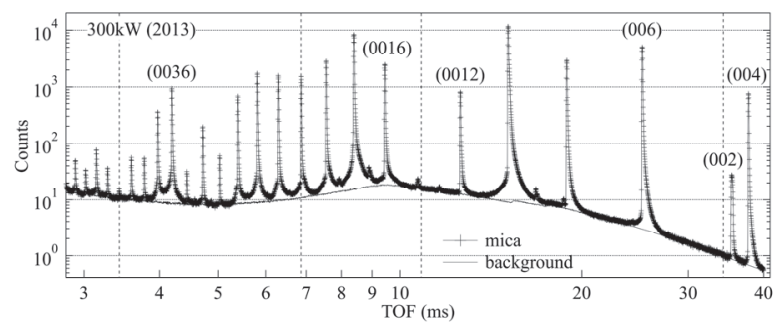

Fig.2 The measured diffraction patterns of mica at 300 $\mathrm{kW}$. The lowest index (002) was diffracted by the 2 nd frame neutrons.

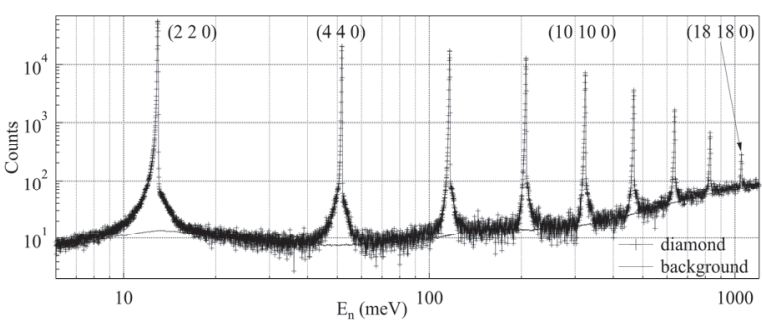

Fig.3 The diffraction pattern of diamond at $200 \mathrm{~kW}$.

The highest index (18 18 0) is observable.

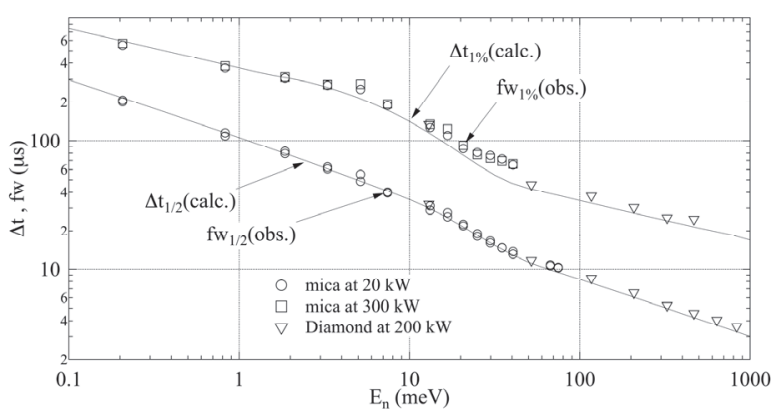

Fig.4 The obtained full-width at half-maximum $\left(\mathrm{fw}_{1 / 2}\right)$ and full-width at 1 percent-maximum $\left(\mathrm{fw}_{1 \%}\right)$ are plotted in the figure with corresponding calculated pulse width $\Delta \mathrm{t}_{1 / 2}$ and $\Delta \mathrm{t}_{1 \%}$.

入門講座ということで，論文には載せないよう な失敗例を最後にひとつ紹介する（実際には，試 料選定においてはかなりの数のトライ\&エラーを 重㸚ている).

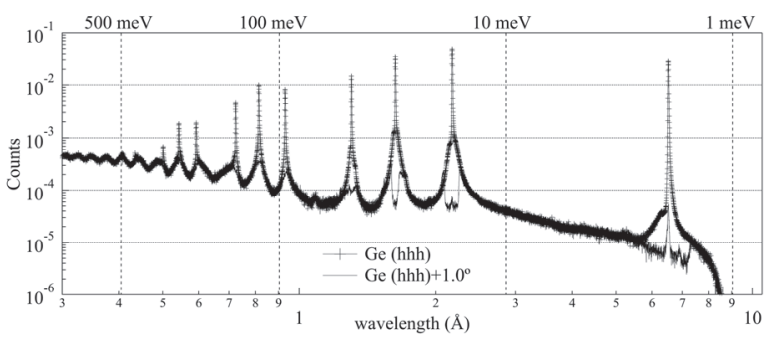

Fig.5 The measured diffraction pattern of germanium rod and its background. Sample size was $\phi 8 \mathrm{~mm} \times \mathrm{h} 30$ $\mathrm{mm}$. Signal to noise ratio was good, but strong diffusive structure was also obtained.

Fig. 5 にゲルマニウムの単結晶を室温測定した 時の回折パターンを示す。十マーク付きがロッキ ングカーブから軸立てした回折条件位置でのデー タ，十マーク無しはそこから試料を $1^{\circ}$ 回した位 置で測定したバックグラウンドデータである. 試 料確認測定のつもりだったので，あまり長時間測 定していないが，off-Bragg の位置でかなり強い diffuse がピークの裾に乗つている. しかも短波長 領域では，その周期が徐々にずれて行っているよ うに見える. MLF の単結晶回折装置 SENJU でど のように見えるか，試してみたいと考えている. 
2.3 熱・冷中性子スペクトル

試料位置での熱・冷中性子のスペクトル測定を 行うにあたり，モデレータからの直達中性子はた とえ数 $\mathrm{kW}$ でも強く，一般的な数気圧の ${ }^{3} \mathrm{He}$ 検出 器では, カウントレートが追いつかず数え落とし が起きる。そこで，熱・冷中性子のスペクトル測 定では, ${ }^{3} \mathrm{He}$ ガス圧を抑えたモニタータイプの ${ }^{3} \mathrm{He}$ 検出器 (検出効率 $10^{-1} \sim 10^{-5}$ ) を複数台用意し, 中 性子強度に合わせて使い分けることとした.また， 計数率が高くなると数え落としが生じる可能性が あるため，ランダムパルスジェネレータの信号を 用いて，不感時間の補正を行った。ランダムなパ ルスは，不感時間がなければ，単位時間あたりの カウントは一定になる。しかしながら，不感時間 があると，その時間だけ単位時間あたりのランダ ムパルスのカウントが減少するので，その減少の 割合に相当する分, 中性子カウント数を補正して いる.

検出器位置での中性子束を得る関係式は次のと おりである。中性子のエネルギー $E_{n}(\mathrm{eV})$ は，ター ゲットへの陽子到達時間（正確には，陽子ビーム を検知する陽子ビームラインのカレントトランス フォーマーからの信号）を０とし，検出器に到達 した飛行時間 $t_{n}(\mathrm{~s})$ から導出する。単位時間当たり のカウント数 $C(/ \mathrm{s})$ とすると, 飛行時間法により検 出器で得られる単位時間・単位飛行時間当たりの カウント数 $d C / d t_{n}\left(/ \mathrm{s}^{2}\right)$ から,

$$
\frac{d}{d E_{n}} \phi\left(E_{n}\right)=\frac{d C}{d t_{n}} \cdot \frac{d t_{n}}{d E_{n}} \cdot \frac{1}{\operatorname{Eff}\left(E_{n}\right)}
$$

という式により, 検出器位置での単位時間 - 単位 エネルギー当たりの中性子束 $d \phi\left(E_{n}\right) / d E_{n}$ $\left(\mathrm{n} / \mathrm{cm}^{2} / \mathrm{eV} / \mathrm{s}\right)$ が得られる。Eff( $\left.E_{n}\right)$ は, $E_{n}$ のときの検 出効率を示寸. $E f f\left(E_{n}\right)$ 検出器固有のもので, 低 検出効率の検出器を用いる場合は，この絶対值を 精度よく測る必要がある。筆者らは，所有するモ ニター類の検出効率としては, メーカー推奨值 (カ タログ值）を使わずに，購入後独自に測った值を 使用している.

我々の目的は, 線源強度の計算值と実測值とを 比較することである. そのため, 検出器位置での 中性子束をいわゆる線源強度 $d S\left(E_{n}\right) / d E_{n}$ に変換す る必要がある。その関係式は次式のようになる。

$$
\frac{d}{d E_{n}} S\left(E_{n}\right)=\frac{d}{d E_{n}} \phi\left(E_{n}\right) \cdot \frac{1}{\operatorname{Trans}\left(E_{n}\right)}
$$

ここで， $\operatorname{Trans}\left(E_{n}\right)$ は， $E_{n}$ のときの輸送率を示す． この輸送率は, モデレータから検出器位置まで, ビームラインコンポーネントを含む幾何学的な形 状 (モデレータ表面積, 検出器面積, コリメータ, スリットサイズ等）に起因するだけでなく，途中 にある空材のアルミニウム合金での散乱や吸収,
同様に途中にある空気などの散乱や吸収も考慮す る必要がある。もし中性子ミラーがある場合は, その反射も考慮する必要がある（BL10には，中 性子ミラーはない)。これらを McStas や PHITS[8] によりシミュレーションし，最終的な輸送率を導 出した. Fig. 6 は，アルミニウム合金（上）と空 気（下）の透過率の計算值を示寸. 冷中性子領域 では，一般的に吸収断面積が大きくなるため, 中 性子が吸収されやすい。
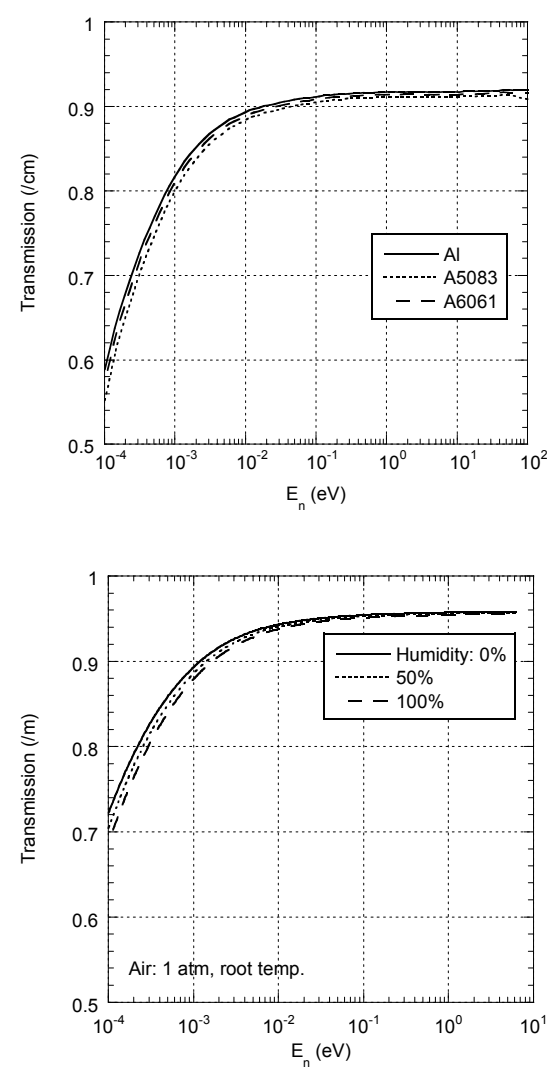

Fig.6 The calculated neutron energy dependence of transmission rates of aluminum alloy (upper) and air (lower)

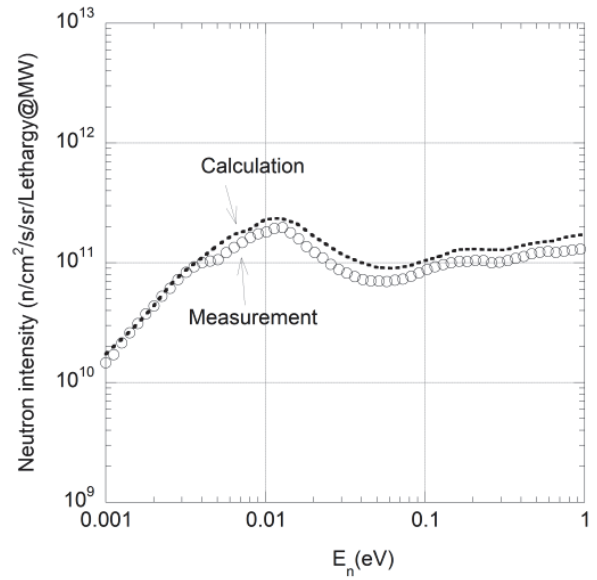

Fig.7 The measured neutron spectrum compared with calculated one. Proton beam power was $4 \mathrm{~kW}$. 
これらの補正を施し，線源強度に変換された実 測值を Fig. 7 に示す. 縦軸の単位は，見やすくす るために，単位エネルギーではなく，単位レサジ 一を使用している。'レサジー’は，原子炉物理学 では一般的なエネルギーの尺度であり，例えば文 献[9]を参考にしていただくと良い. 計算值も合わ せて示す。実測值の誤差は，10\%以下である。計 算值は，J-PARCの web 上のデータを元にしてい るが, 線源集合体の冷却水種の違い（web データ： $\mathrm{D}_{2} \mathrm{O}$ 体系，記載計算值及び実際: $\mathrm{H}_{2} \mathrm{O}$ 体系）の補 正を行っている。Fig. 7 を見る限り，非常に良い 一致を示している。しかしながら，実は驚くべき 結果である。これらの過程は, $3 \mathrm{GeV}$ 陽子ビーム の入射から出発し, 水銀ターゲット, 反射体, モ デレータを経由して, ビーム孔を通り, $\mathrm{meV}$ の中 性子が検出器に到達するまでである。強度も $2 \times 10^{15} \mathrm{proton} / \mathrm{s}$ の陽子が，検出器位置では， $5 \times 10^{7}$ $\mathrm{n} / \mathrm{cm} / \mathrm{s}$ に変化する. それらエネルギーで約 12 桁, 強度で約 8 桁に渡る事象が，計算と実験で，染意 的な調整パラメータもなく, 一致するのである [10].

さて，検出効率を低くすれば，中性子強度が上 がって行っても測定できると期待したが，実際の ところそうではなかった。大強度になるにつれ， 検出器空材のアルミニウムの放射化 $\left({ }^{27} \mathrm{Al}(\mathrm{n}, \gamma){ }^{28} \mathrm{Al}\right)$ により生成される ${ }^{28} \mathrm{Al}$ (半減期 : 2.24 分) から発 生する $\beta$ 線（最大エネルギー:2.86 MeV）がバック グランドとなり，プリアンプでの中性子と $\beta$ 線や $\gamma$ 線の弁別が困難になるのである。特に， ${ }^{3} \mathrm{He}$ ガス の少ない低検出効率のモニターほど, 実効的な $\mathrm{S} / \mathrm{N}$ 比が悪くなり, 中性子イベント $\left({ }^{3} \mathrm{He}\right.$ ガスの 量に比例）とそれ以外のイベント（例えばアルミ 二ウムの量に比例）との分離が難しくなることが 分かっている. MLF のモニター開発チームで, こ の問題を解決するために, 研究を進めている [11].

\section{4 熱・冷中性子強度測定}

金箔の放射化法による中性子強度の測定は，古 くから行われている一般的な測定方法であり，

${ }^{197} \mathrm{Au}(\mathrm{n}, \gamma){ }^{198} \mathrm{Au}$ 反応を利用し, 中性子照射により生 成された ${ }^{198} \mathrm{Au}$ (半減期 2.697 日）からの $\beta^{-}$崩壊に 伴う線（エネルギー:主に $411 \mathrm{keV}$ ) を計数するこ とで, 中性子量を推定するものである. また，金 の共鳴吸収の影響を除くため, カドミウムカバー 有無の 2 回測定している。この測定方法は，金の 吸収断面積が大きいことや，簡便かつ補正が少な いなら゙，利点が大きい. 反面, 照射場の中性子ス ペクトルデータ (中性子強度のエネルギ一依存性) が必要なことや，オンラインでの測定ができない ことが久点である。

BL10 での測定では， $15 \times 15 \times 0.05 \mathrm{~mm}^{3}$ の金筞を 測定位置に置いて, 10 分程度照射した. その後, ゲルマニウム検出器で, 放射化した金箔からの $\gamma$ 線を計数し, 中性子強度へと変換した。

最初の測定は, $4 \mathrm{~kW}$ 出力の時に, $14 \mathrm{~m}$ 位置に
金䈃を設置し，照射した。この測定から得られた 中性子強度は， $2.8 \times 10^{7} \mathrm{n} / \mathrm{cm}^{2} @ 1 \mathrm{MW}$ であった（実 験誤差は, $5 \%$. 主に, 陽子ビームモニターの精度). 計算值が， $2.3 \times 10^{7} \mathrm{n} / \mathrm{cm}^{2} @ 1 \mathrm{MW}($ 計算の統計誤差 は，10\%以下）だったので，良い一致を示してい る[12]. この測定で大事なのは，コリメータであ る. 金箔照射を 2 度（カドミウムカバーの有無） 同一条件で測定する必要があるために，測定条件 が異ならないようにコリメータを再現良く設置す る必要がある。また，その下流での ${ }^{3} \mathrm{He}$ 中性子モ ニターによる中性子スペクトルをその都度測定す るなど，整合性のチェックができるように工夫し ている.

この金筞の測定は，現在でも定期的に実施して いる。また，他の BL でも必要に応じ実施してい る.

\section{5 陽子ビーム運転パラメータとの相関}

中性子強度の陽子ビームの位置の依存性につい ては，何度か加速器スタディ時に実測を行ってお り，ほぼ計算通りであることが分かっている。一 方, 中性子強度の陽子ビーム強度依存性は, 単純 な比例関係ではなく, 陽子ビーム強度が増加する ほど，中性子強度の増加量が減少していくことが 明らかとなっている (Fig. 8 参照)。これは, 水銀 ターゲット容器のキャビテーション損傷を抑える 必要から, 陽子ビームの最大電流密度を抑えるた めに，水銀ターゲットに入射するビームプロファ イルを加速器出力上昇に伴い拡げていることが原 因である可能性が高い. 今後も加速器出力の増強 に合わせ，この中性子強度依存性を観測する必要 があると考えている[13].

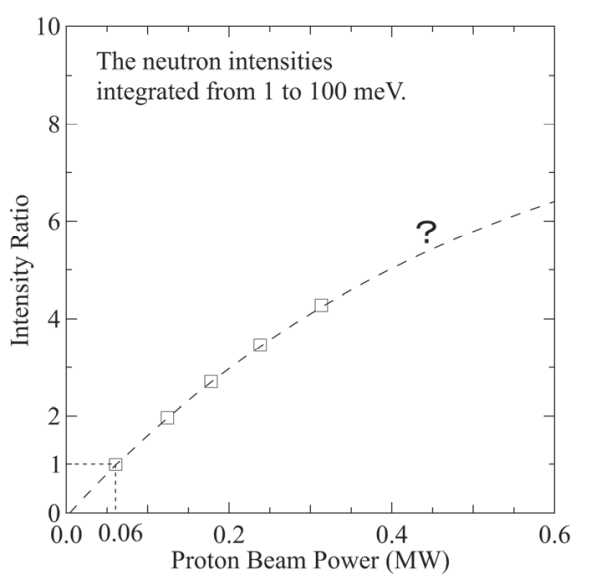

Fig.8 The measured neutron intensities and fitted curve with various proton beam powers. The measured values are normalized by the value at $0.06 \mathrm{MW}$. 


\section{3.おわりに}

特性試験装置の提案・建設に際しては, 相当な 逆風が吹き荒れましたが，何とか今日まで内外の ユーザーと共に成果を出しつつやって来られまし た. すでに半数近くの当初提案者が本装置グルー プを去りましたが，1MW の大強度ビーム実測の 実現まで，もう一息の頑張りと思います。

また，BL22（螺鈿）稼働開始により，イメージ ング実験課題が BL10 から無くなりますので, 今 後は多少課題審查倍率が下がると期待されます。

他の装置群では実現不可能な, 中性子散乱以外の 実験アイデアのある方は，筆者までご相談頂けれ ば幸いです。

参考文献

[1] 波紋 18, 159 (2008).

[2] 波紋 17, 187 (2007).

[3] 波紋 20,34 (2010).

[4] J-PARC MLF ホームページ

http:/j-parc.jp/researcher/MatLife/ja/instrumentation/ index.html

[5] P. Willendrup et al., Physica B, 350 E73 (2004).

[6] S. Ikeda et al., Nucl. Instr. Method A239 536 (1985).

[7] K. Oikawa et al., JPS Conf. Proc. 1, 014012 (2014).

[8] T. Sato, et al., J. Nucl. Sci. Technol. 50, 913 (2013).

[9] 原子炉工学大要, 長谷川修ら著, 養賢堂発行, 第 8 版 (1991).

[10] M. Harada et al, Proc. Nucl. Sci. Tecnol 2872 (2011).

[11] S. Takata et al., to be submitted in Proc. $2^{\text {nd }}$ Int. Symp. Sci. J-PARC (2014).

[12] F. Maekawa et al., Nucl. Instr Method A620 159 (2010).

[13] M. Harada et al., to be submitted in Proc. $2^{\text {nd }}$ Int. Symp. Sci. J-PARC (2014). 